\title{
Short-term temperature effects on oxygen and sulfide cycling in a hypersaline cyanobacterial mat (Solar Lake, Egypt)
}

\author{
Andrea Wieland ${ }^{1, *}$, Michael Kühl ${ }^{2}$ \\ ${ }^{1}$ Max Planck Institute for Marine Microbiology, Microsensor Research Group, Celsiusstr. 1, 28359 Bremen, Germany \\ ${ }^{2}$ Marine Biological Laboratory, University of Copenhagen, Strandpromenaden 5, 3000 Helsingor, Denmark
}

\begin{abstract}
We investigated short-term temperature effects on oxygen and sulfide cycling with $\mathrm{O}_{2}$, $\mathrm{pH}$, and $\mathrm{H}_{2} \mathrm{~S}$ microsensors in a hypersaline cyanobacterial mat, incubated in darkness and at a downwelling irradiance, $E_{\mathrm{d}}$ (PAR), of $425 \mu \mathrm{mol}$ photons $\mathrm{m}^{-2} \mathrm{~s}^{-1}$ in a laboratory. The incubation temperature was increased from 25 to $40^{\circ} \mathrm{C}$ in $5^{\circ} \mathrm{C}$ intervals. Areal rates of gross and net photosynthesis, of $\mathrm{O}_{2}$ consumption in the aphotic zone and of dark $\mathrm{O}_{2}$ consumption were maximal at $30^{\circ} \mathrm{C}$, i.e. close to the in situ temperature of the natural habitat. Areal rates of dark oxygen consumption showed only a minor temperature dependence as $\mathrm{O}_{2}$ consumption was diffusion limited at all temperatures. Sulfide production increased strongly with temperature in both the dark and light incubated mat $\left(Q_{10}=1.8\right.$ to 3.2$)$, and this led to saturation of sulfide oxidation and an increased sulfide efflux out of the dark incubated mat, which was maximal at $35^{\circ} \mathrm{C}$. In the uppermost layer of the dark incubated mat, $\mathrm{pH}$ decreased due to aerobic respiration, sulfide oxidation and fermentation, and this decrease was enhanced with temperature. In the light incubated mat, the thickness of the photic zone decreased with temperature from 0.9 to $0.5 \mathrm{~mm}$. Oxygen penetration and peak oxygen concentration decreased with temperature, whereas the upper sulfide boundary and thus the zone of sulfide oxidation rose closer to the mat surface in the light incubated mat. Areal rates of sulfide oxidation increased more than 2-fold from 25 to $40^{\circ} \mathrm{C}$ in the light incubated mat. The relative contribution of sulfide oxidation to oxygen consumption in the aphotic zone increased significantly with temperature, indicating that at elevated temperatures incomplete sulfide oxidation occurred in the light incubated mat. Both the photosynthetically induced $\mathrm{pH}$ maximum and the overall $\mathrm{pH}$ of the mat decreased with increasing temperature due to enhanced heterotrophic activity, sulfide oxidation, and a changed depth distribution of these processes. Our data demonstrate a close coupling of oxygen and sulfur cycling in hypersaline microbial mats, that is strongly regulated by temperature.
\end{abstract}

KEY WORDS: Photosynthesis - Respiration - Sulfate reduction - Sulfide oxidation - Microsensor . Temperature regulation

\section{INTRODUCTION}

Microbial mats are benthic ecosystems where primary production, aerobic and anaerobic heterotrophic and. chemolithotrophic processes occur in close association (van Gemerden 1993). In hypersaline environments, the elevated salinity precludes survival of most higher organisms and thus reduces grazing pressure and bio-

·E-mail:mblaw@get2net.dk turbation, leading to the development of thick and welllaminated microbial mats. Such predominantly microbial systems are well suited to studying the regulation and interaction of microbial processes involved in benthic carbon cycling. Furthermore, many microbial mat communities exhibit a striking similarity to Precambrian stromatolite communities in the fossil record (Schopf \& Klein 1992). Biogeochemical and microbiological studies of recent microbial mats can, therefore, provide important information for interpreting the stable isotope signatures of carbon cycling left in the fossil record. 
One of the best studied hypersaline environments is Solar Lake (Sinai, Egypt), a small lake characterized by an exceptional limnological cycle. During winter (and most of the year) the lake is stratified, with colder and less saline surface waters above the thermocline. Overturn to holomixis occurs in summer due to a salinity increase of the surface waters, caused by increasing evaporation towards summer (Por 1969, Cohen et al. 1977). During the stratification period, steep gradients of temperature, $\mathrm{pH}$, redox potential, salinity, oxygen, and sulfide develop in the Solar Lake water column (Cohen et al. 1977). The bottom of Solar Lake is covered by well-developed microbial mats (Krumbein et al. 1977, Jørgensen et al. 1983), with high concentrations of mostly autochthonous organic matter in the upper few $\mathrm{cm}$ of the shallow-water mats (Krumbein et al. 1977, Aizenshtat et al. 1984). Although high primary production occurs in the uppermost millimeters of the mat, the yearly biomass accretion rate is relatively low, indicating high remineralization rates due to aerobic and anaerobic degradation (Krumbein et al. 1977). This indication is also supported by the high abundance of aerobic heterotrophs (Krumbein et al. 1977), anaerobic heterotrophs and, especially, of sulfate-reducing bacteria (Jørgensen \& Cohen 1977) in the upperinost layer of the mat. Heterotrophic piocesses can supply $\mathrm{CO}_{2}$ to the autotrophic community of the mat, alleviating the inorganic carbon limitation of photosynthesis (Canfield \& Des Marais 1993, Teske et al. 1998), which is indicated by the enrichment in heavy carbon isotope (Schidlowski et al. 1984).

The physico-chemical conditions in microbial mats are characterized by pronounced fluctuations. Chemical gradients in the mat change drastically within a diel cycle (Revsbech et al. 1983). Solar radiation induces oxygenic photosynthesis in the mat, resulting in a pronounced build-up of oxygen supersaturation in the uppermost 1 to $3 \mathrm{~mm}$ thick surface layer above the sulfidic zone. During the night, sulfide accumulates and rises closer to the mat surface, with only minor oxygen penetration into the mat (Revsbech et al. 1983). Thus, the inhabiting microorganisms have to be physiologically flexible and fairly well adapted to the prevailing fluctuating conditions, as has already been demonstrated for the sulfate-reducing bacteria and cyanobacteria (Cohen et al. 1986, Jørgensen et al. 1986, Krekeler et al. 1997, Krekeler et al. 1998, Teske et al. 1998). Besides the light regime, temperature also changes on a diel basis (Revsbech et al. 1983). Temperature variations additionally occur throughout an annual cycle, due to the limnological cycle in the water column of the lake. Jorgensen et al. (1979) measured diel temperature variations at the mat surface both in winter and summer, ranging from 27 to $33^{\circ} \mathrm{C}$ in summer (September) and from 22 to $27^{\circ} \mathrm{C}$ in winter (March).
Temperature is an important environmental variable controlling benthic metabolic activities. Temperature effects on benthic primary production (e.g. Rasmussen et al. 1983, Grant 1986), aerobic respiration (Thamdrup et al. 1998) and sulfate reduction (e.g. Abdollahi \& Nedwell 1979, Skyring 1987, Westrich \& Berner 1988) have been investigated in marine sediments. Only little is known about the temperature regulation of carbon cycling in marine microbial mats and relatively few studies address the temperature regulation of metabolic processes in mats (Skyring et al. 1983, Javor \& Castenholz 1984, Jørgensen 1994b). In a detailed study of the biogeochemistry of hypersaline mats, Canfield \& Des Marais (1993) considered the major microbial processes (oxygenic photosynthesis, sulfate reduction, oxygen consumption due to aerobic respiration and sulfide oxidation). However, their measurements were limited to 2 different temperatures.

Whereas several microsensor studies of oxygen and sulfur cycling in hypersaline mats have been reported (e.g. Jørgensen et al. 1979, 1983, Revsbech et al. 1983), we are not aware of studies where the effect of temperature on oxygen and sulfide turnover, and their coupling to each other, has been addressed in detail. In this study, microsensor measurements in Solar Lake microbial mats were performed to investigate shortterm temperature effects on the cycling of dissolved oxygen and sulfide in dark and light conditions. The goal was to gain detailed information on how temperature affects (1) the major autotrophic and heterotrophic processes involved in carbon cycling, and (2) the balance between these processes in a hypersaline mat.

\section{MATERIAL AND METHODS}

Samples and experimental set-up. Microbial mat samples (approximately $30 \times 25 \times 4 \mathrm{~cm}$ ) were collected by snorkeling in the shallow ( 0.4 to $0.5 \mathrm{~m}$ deep) eastern part of the hypersaline Solar Lake (Sinai, Egypt) in November 1996. The in situ temperature at the mat surface was $27.5^{\circ} \mathrm{C}$ and the salinity of the overlying water was $105 \%$, as determined by a portable refractometer (Atago, S-28E, Japan). The mat sample was transferred within a few hours to the Interuniversity Institute in Eilat (Israel). During transport, the mat sample was kept moist in a plastic dish with only a thin film of Solar Lake water above the mat surface in order to avoid excess sulfide accumulation.

In the laboratory, a mat subsample (approximately $6 \times 4 \times 2.5 \mathrm{~cm}$ ) was mounted in a flow chamber modified from Lorenzen et al. (1995). The subsample was embedded in agar $(1.5 \%[\mathrm{w} / \mathrm{v}]$ in filtered Solar Lake water), leaving the mat surface flush with the surrounding agar surface. A submersible water pump (E-Heim, 
Germany) was connected to the flow chamber and generated a constant flow of filtered and aerated Solar Lake water over the mat surface. The temperature of the Solar Lake water reservoir was adjusted to $\pm 0.5^{\circ} \mathrm{C}$ via a heat exchanging metal coil connected to a thermostat (Julabo, F32-HC, Germany). In the experimental set-up, the salinity was determined with a conductivity meter (WTW, LF 197, Germany), which was calibrated by readings with a refractometer.

The flow chamber was illuminated with a fiber-optic halogen light source (Schott, KL 1500, Germany), and the downwelling irradiance, $E_{d}$ (PAR), at the mat surface was adjusted to $425 \mu \mathrm{mol}$ photons $\mathrm{m}^{-2} \mathrm{~s}^{-1}$, as determined by an underwater quantum irradiance meter (LiCor, LI-250, USA). For accurate determination of $E_{\mathrm{d}}$ (PAR), the quantum sensor was placed at the same distance from the light source and with the same amount of overlying Solar Lake water as the microbial mat. Experimental light-dark shifts were controlled by an electronic shutter (Vincent Ass., Uni-blitz VS35S2TO, USA) that was inserted in the light path between the lamp and the mat sample.

Microsensors. Clark-type $\mathrm{O}_{2}$ (Revsbech 1989) and $\mathrm{H}_{2} \mathrm{~S}$ (Jeroschewski et al. 1996, Kühl et al. 1998) microsensors, and glass pH microelectrodes (Revsbech \& Jørgensen 1986) were used to measure the temperature-dependent distribution of oxygen and sulfide in the light and dark incubated Solar Lake mat. The $\mathrm{O}_{2}$ microsensor had a tip diameter of $<10 \mu \mathrm{m}$, a stirring sensitivity of $<2 \%$, and a $t_{90}$ response time of $<0.5 \mathrm{~s}$. The $\mathrm{H}_{2} \mathrm{~S}$ microsensor, which was coated with black enamel paint to avoid light interference on the measuring signal (Kühl et al. 1998), had a tip diameter of $<20 \mu \mathrm{m}$. The length of the $\mathrm{pH}$-sensitive glass at the tip of the $\mathrm{pH}$ microelectrode was $<100 \mu \mathrm{m}$, with a tip diameter of $<15 \mu \mathrm{m}$.

Microsensor calibrations. The $\mathrm{O}_{2}$ microsensor was linearly calibrated at each experimental temperature from readings of microsensor current in the anoxic part of the mat ( $0 \%$ oxygen) and in the overlying air saturated Solar Lake brine (100\% air saturation). Dissolved oxygen concentrations of air saturated brine at experimental temperatures and salinities were calculated according to Sherwood et al. (1991).

The glass $\mathrm{pH}$ microelectrodes were calibrated in standard buffer solutions (Mettler Toledo, Switzerland) at different temperatures. In one case (at $30^{\circ} \mathrm{C}$ ), the $\mathrm{pH}$ microsensor was not calibrated at the measuring temperature. Therefore, the calibration slope obtained at $25^{\circ} \mathrm{C}$ was corrected for temperature, based on an average of the relative temperature-dependent change of the calibration slope, as measured with 4 other $\mathrm{pH}$ microelectrodes. In the experimental set-up, the $\mathrm{mV}$ signals of the $\mathrm{pH}$ microelectrodes and the $\mathrm{pH}$ of the overlying Solar Lake water, which was determined with a commercial pH meter (Mettler Toledo, MA 130 , Switzerland) at $25^{\circ} \mathrm{C}$, was used to correct for salinity (parallel shift of the calibration curve). For salinity corrections at elevated experimental temperatures $\left(>25^{\circ} \mathrm{C}\right)$, the $\mathrm{pH}$ reading of the macroelectrode at $25^{\circ} \mathrm{C}$ was corrected for the temperature increase, assuming that the $\mathrm{pH}$ decreases $0.0114 \mathrm{pH}$ units per $1^{\circ} \mathrm{C}$ temperature increase according to Grasshoff (1983)

Calibration of the $\mathrm{H}_{2} \mathrm{~S}$ microsensor was done in an Erlenmeyer flask closed with a silicon rubber stopper with holes for (1) the microsensor, (2) a tube through which a constant flow of nitrogen gas was flushed into the flask, and (3) an inlet for addition of defined volumes of $\mathrm{Na}_{2} \mathrm{~S}$ stock solution to the stirred anoxic buffer solution (200 mM phosphate buffer, pH 7). After each addition of $\mathrm{Na}_{2} \mathrm{~S}$, a subsample was taken out and fixed in zinc acetate. The samples were stored dark and cold prior to the determination of total dissolved sulfide by the methylene blue method (Cline 1969). The $\mathrm{H}_{2} \mathrm{~S}$ concentration in the analyzed samples was calculated according to the equation (Jeroschewski et al. 1996)

$$
\left[\mathrm{H}_{2} \mathrm{~S}\right]=\left[\mathrm{S}_{\text {lot }}\right] /\left(1+\frac{K_{1}}{\left[\mathrm{H}_{3} \mathrm{O}^{+}\right]}\right)
$$

where $\left[S_{t o t}\right]$ is the total sulfide concentration, and $K_{t}$ is the first dissociation constant of the sulfide equilibrium, assuming a $\mathrm{p} K_{1}$ of 7.05 (Kühl \& Jørgensen 1992, and references therein). The slope of the $\mathrm{H}_{2} \mathrm{~S}$ calibration curve, determined by linear regression, was used to calculate the distribution of $\mathrm{H}_{2} \mathrm{~S}$ in the mat. Subsequently, the total sulfide distribution in the mat was calculated by use of Eq. (1) with measured $\mathrm{H}_{2} \mathrm{~S}$ and $\mathrm{pH}$ values at corresponding depths. In the latter case, the $\mathrm{p} K_{1}$ was corrected for temperature and salinity, as linearly extrapolated from the $p K_{1}^{*}$ measured in artificial Dead Sea brines and the $\mathrm{p} K_{1}$ at $25^{\circ} \mathrm{C}$ in non-saline medium (Hershey et al. 1988). The slope of the $\mathrm{H}_{2} \mathrm{~S}$ calibration curve was corrected for temperature based on previously obtained data (C. Steuckart \& A. Wieland unpubl. results). The slope decreased $5.6 \%$ at $30^{\circ} \mathrm{C}$, $10.7 \%$ at $35^{\circ} \mathrm{C}$ and $13.1 \%$ at $40^{\circ} \mathrm{C}$ as compared to the slope of the calibration curve at $25^{\circ} \mathrm{C}$. In the following, $\mathrm{H}_{2} \mathrm{~S}$ denotes dissolved hydrogen sulfide, whereas $\mathrm{S}_{\text {tot }}$ or sulfide denotes total sulfide, i.e. the sum of $\mathrm{H}_{2} \mathrm{~S}_{\text {, }}$ $\mathrm{HS}^{-}$, and $\mathrm{S}^{2-}$.

Microprofile measurements. The $\mathrm{H}_{2} \mathrm{~S}$ and the $\mathrm{pH}$ microsensors were glued together, after orienting the tips of both microsensors as close as possible in the same horizontal plane under a microscope. The $\mathrm{H}_{2} \mathrm{~S}$ and the $\mathrm{pH}$ microsensors were fixed together with the $\mathrm{O}_{2}$ microsensor (within an area of approximately $1 \mathrm{~cm}^{2}$ of the mat surface) in a motor driven micromanipulator (Oriel, Encoder Mike, USA; Märzhäuser, MD4 modified, Germany). The $\mathrm{O}_{2}$ and $\mathrm{H}_{2} \mathrm{~S}$ microsensors were connected to fast-responding picoammeters. The $\mathrm{pH}$ 
microelectrode was connected to a high impedance millivoltmeter. The microsensors were positioned on the mat surface by use of the motorized micromanipulator, while watching them through a dissection scope (Zeiss, SV6, Germany). The measuring signals were recorded with a strip chart recorder (Servogor, 124 plus, UK) and with a computer data acquisition system (National Instruments, Labview, USA) that also controlled the micromanipulator. Profiles of $\mathrm{O}_{2}, \mathrm{pH}$ and $\mathrm{H}_{2} \mathrm{~S}$ were measured with a vertical depth resolution of $100 \mu \mathrm{m}$. Microsensor measurements were started 1 to $3 \mathrm{~h}$ after changing the temperature conditions. Then several measurements were performed to ensure the establishment of a new steady-state, which was normally reached within a few hours after the temperature change.

Gross photosynthesis measurements. Gross photosynthesis was measured with fast-responding $\mathrm{O}_{2}$ microelectrodes by means of the light-dark shift technique (Revsbech \& Jørgensen 1983). Precisely defined light-dark shifts were achieved with the electronic shutter (see above), which was triggered via the data acquisition software. A photodiode close to the shutter registered the moment of darkening. The initial rate of $\mathrm{O}_{2}$ depletion was calculated automatically by the data acquisition software via linear regression on the acquired data points over the initial 1 to $2 \mathrm{~s}$ of darkening. Gross photosynthesis was recorded in steps of $100 \mu \mathrm{m}$ vertical depth intervals. The distribution of the volumetric gross photosynthetic rates with depth is given as nmol $\mathrm{O}_{2} \mathrm{~cm}^{-3}$ (porewater) $\mathrm{s}^{-1}$ (Revsbech et al. 1981). In the following, the photic zone refers to the zone in the mat where oxygenic photosynthesis could be detected by the light-dark shift technique. The aphotic zone refers to the oxic zone below the photic zone.

Calculations. Depth-integrated rates of gross photosynthesis, i.e. areal gross photosynthesis, were calculated from the porosity corrected volumetric rates in the photic zone. The mat porosity, $\phi$, was assumed to be 0.9 (Jørgensen \& Cohen 1977, Jørgensen et al. 1979). Areal rates of net photosynthesis and dark $\mathrm{O}_{2}$ consumption were calculated from the linear $\mathrm{O}_{2}$ gradient $\left(\frac{\mathrm{d} C(z)}{\mathrm{d} z}\right)$ in the diffusive boundary layer above the mat surface (Jørgensen \& Revsbech 1985 , Jensen \& Revsbech 1989) according to Fick's first law of (1-dimensional) diffusion:

$$
J_{0}=-D_{0} \frac{\mathrm{d} C(z)}{\mathrm{d} z}
$$

where $D_{0}$ is the free solution molecular diffusion coefficient of $\mathrm{O}_{2}$, and $J_{0}$ is the $\mathrm{O}_{2}$ flux towards the mat surface (dark incubated mat) or towards the air saturated overlying brine (light incubated mat), respectively. Positive values of $J_{0}$ indicate a net $\mathrm{O}_{2}$ import into the mat, whereas negative values of $J_{0}$ indicate a net $\mathrm{O}_{2}$ export out of the mat.

The photosynthetically produced $\mathrm{O}_{2}$ diffuses not only out of the mat into the overlying brine, but also diffuses into the aphotic zone of the mat. This downward $\mathrm{O}_{2}$ flux out of the photic zone, $J_{5^{\prime}}$ equals the areal $\mathrm{O}_{2}$ consumption in the aphotic zone below (Jensen \& Revsbech 1989, Kühl et al. 1996). $J_{s}$ was calculated as:

$$
J_{\mathrm{s}}=-\phi D_{\mathrm{s}}(z) \frac{\mathrm{d} C(z)}{\mathrm{d} z}
$$

where $\frac{\mathrm{d} C(z)}{\mathrm{d} z}$ is the $\mathrm{O}_{2}$ concentration gradient at the lower boundary of the photic zone, i.e. the tangent to that point where the concavity of the $\mathrm{O}_{2}$ profile changes direction. At lower incubation temperatures, this point was located slightly below the lower boundary of the photic zone. The sediment diffusion coefficient, $D_{\mathrm{s}}$, was calculated from the free solution molecular diffusion coefficient, $D_{0}$, and the mat porosity, $\phi$, according to Ullman \& Aller (1982):

$$
D_{\mathrm{s}}=\phi^{2} D_{0}
$$

The free solution diffusion coefficient of $\mathrm{O}_{2}$ was taken from Broecker \& Peng (1974) and corrected for temperature and salinity according to Li \& Gregory (1974).

Net production and consumption zones of $S_{\text {tot }}$ throughout the sulfidic zone of the mat were calculated by using a numerical procedure for the interpretation of measured steady-state microprofiles (Berg et al. 1998). This procedure is based on a series of least square fits to the measured concentration profiles, assuming an increasing number of production and consumption zones. The fits are compared by statistical $F$-testing, resulting in the simplest production-consumption profile, which reproduces the measured concentration profiles within the chosen statistical accuracy (more details in Berg et al. 1998). For this analysis, $\phi$ and $D_{s}$ were estimated as for the calculation of $J_{s}$. The diffusion coefficient $D_{0}\left(\mathrm{~S}_{\text {tot }}\right)$ was calculated from $D_{0}\left(\mathrm{O}_{2}\right)$ assuming the same ratio between both diffusion coefficients as between the whole sediment diffusion coefficients $\left(D_{5}\right)$ in the mat, where $D_{5}\left(S_{\text {tot }}\right)=0.64 D_{5}\left(O_{2}\right)$ (Jørgensen et al. 1979). Areal rates of net sulfide production/consumption were obtained by multiplying the calculated volumetric rates by the thickness of the reaction zones.

\section{RESULTS}

\section{Mat structure and composition}

The mat structure was compacted and finely layered with a smooth gelatinous ca $1 \mathrm{~mm}$ thick brownishorange surface layer. This surface layer was dominated 
by halotolerant unicellular cyanobacteria, most probably belonging to the Halothece cluster (Garcia-Pichel et al. 1998). A ca $0.5 \mathrm{~mm}$ thick dark green band below the surface layer was dominated by filamentous cyanobacteria, mainly Microcoleus chthonoplastes. At $35^{\circ} \mathrm{C}$, a macroscopic change of the mat surface was observed. The original brownish-orange color of the mat surface changed to greenish-white. After the experiment, and, thus, after measurements at $40^{\circ} \mathrm{C}$, the mat sample was frozen in liquid nitrogen. Light microscopy on thawed samples revealed that the surface layer was now not only dominated by unicellular cyanobacteria, but also by filamentous cyanobacteria (mainly M. chthonoplastes) and Chloroflexus-type filamentous bacteria. Additionally, the whitish appearance of the surface layer was due to accumulation of elemental sulfur, mainly associated with small bacterial cells resembling Thiocapsa roseopersicina, a non-motile, physiological versatile purple sulfur bacterium inhabiting microbial mats (de Wit \& van Gemerden 1987).

\section{Microprofiles of $\mathrm{O}_{2}, \mathrm{pH}, \mathrm{S}_{\text {tot }}$ and photosynthesis}

In Fig. 1 steady-state $\mathrm{O}_{2}, \mathrm{pH}$ and $\mathrm{S}_{\text {tot }}$ profiles in the dark and light $\left(425 \mu \mathrm{mol}\right.$ photons $\left.\mathrm{m}^{-2} \mathrm{~s}^{-1}\right)$ incubated Solar Lake mat are shown. Dark $\mathrm{O}_{2}$ profiles were only slightly affected by changes in temperature, as $\mathrm{O}_{2}$ was completely consumed in the uppermost $0.2 \mathrm{~mm}$ of the mat even at $25^{\circ} \mathrm{C}$ (Fig. 1, left panel). In the light incubated mat, $\mathrm{O}_{2}$ penetration and maximal $\mathrm{O}_{2}$ concentration were highest at $25^{\circ} \mathrm{C}$ as compared to the other incubation temperatures (see also Table 1). The oxic zone was $3.7 \mathrm{~mm}$ thick and the maximal $\mathrm{pO}_{2}$ at $0.8 \mathrm{~mm}$ depth was $>7$ times air saturation. With increasing incubation temperature, $\mathrm{O}_{2}$ penetration and peak $\mathrm{O}_{2}$ concentration in the mat showed a decreasing trend (see also Table 1). The thickness of the photic zone decreased with temperature, while maximal volumetric rates of gross photosynthesis showed an increasing trend with temperature (Table 1).

At $25^{\circ} \mathrm{C}, \mathrm{pH}$ decreased strongly in the uppermost layer of the dark incubated mat due to aerobic respiration, fermentation and sulfide oxidation (Fig. 1, central panel). The $\mathrm{pH}$ dropped to a minimum value of 7.3 at 0.7 to $1.3 \mathrm{~mm}$ depth and then increased to $\mathrm{pH} 7.4$. The $\mathrm{pH}$ decrease in the uppermost part of the mat became more pronounced with temperature, reaching a minimal pH of 7.0 at $40^{\circ} \mathrm{C}$. The $\mathrm{pH}$ in the deeper parts of the mat also became more acidic with temperature and decreased approximately $0.4 \mathrm{pH}$ units between 25 and $40^{\circ} \mathrm{C}$. In the light incubated mat, photosynthetic $\mathrm{CO}_{2}$ fixation led to a broad maximum in $\mathrm{pH}$ (up to $\mathrm{pH}$ 9.5), indicating a predominance of photosynthesis at $25^{\circ} \mathrm{C}$. Below this peak, pH strongly decreased due to aerobic respiration, fermentation and sulfide oxidation. The photosynthetically induced $\mathrm{pH}$ maximum decreased with temperature down to a peak $\mathrm{pH}$ of 8.2 at $40^{\circ} \mathrm{C}$ Additionally, the zone below the $\mathrm{pH}$ maximum became more acidic with temperature.

Sulfide profiles, calculated from the measured $\mathrm{pH}$ and $\mathrm{H}_{2} \mathrm{~S}$ profiles, were strongly affected by temperature both in the dark and in the light incubated mat (Fig. 1, right panel). In the dark incubated mat, steep gradients of $S_{10}$ developed in response to the temperature increase. Maximal concentrations of $1552 \mu \mathrm{M}$ of total sulfide, corresponding to $624 \mu \mathrm{M} \mathrm{H}_{2} \mathrm{~S}$ at the prevailing $\mathrm{pH}$ of 7.2 at that depth, were detected at $35^{\circ} \mathrm{C}$ in the dark incubated mat, as compared to $588 \mu \mathrm{M}$ ( $216 \mu \mathrm{M} \mathrm{H}_{2} \mathrm{~S}, \mathrm{pH} 7.4$ ) at $25^{\circ} \mathrm{C}$. In the dark, net sulfide production increased with temperature, and increasing amounts of sulfide diffused out of the mat at higher temperatures. The upper boundary of sulfide in the light incubated mat, i.e. the oxic-anoxic interphase, moved upwards when the temperature was increased. Also in the illuminated mat, steep sulfide gradients developed with increasing temperature as a result of enhanced sulfide production.

\section{Oxygen conversion}

Fig. 2 shows areal rates of gross and net photosynthesis, and dark $\mathrm{O}_{2}$ consumption as a function of temperature. Net photosynthesis was affected most strongly by temperature and decreased significantly at temperatures above $30^{\circ} \mathrm{C}$. Areal rates of dark $\mathrm{O}_{2}$ consumption were much less influenced by increasing temperatures. Dark $\mathrm{O}_{2}$ consumption, areal gross and net photosynthesis all exhibited a maximum at $30^{\circ} \mathrm{C}$, and showed a decreasing trend with higher temperatures. The mismatch at 25 and $30^{\circ} \mathrm{C}$ between gross and net photosynthesis has been observed and described previously in a similar microbial mat from a hypersaline lagoon in Spain (E. H. G. Epping \& M. Kühl unpubl.). If rates of net photosynthesis are higher than apparent rates of gross photosynthesis, negative $\mathrm{O}_{2}$ consumption rates would result. For this reason, the calculation of $\mathrm{O}_{2}$ consumption rates in the light was neglected. Nevertheless, rates of net photosynthesis were minimal at $35^{\circ} \mathrm{C}$, indicating maximal $\mathrm{O}_{2}$ consumption in the light. Furthermore, gross photosynthesis was minimal at $25^{\circ} \mathrm{C}$ with maximal $\mathrm{O}_{2}$ penetration (Table 1), indicating minimal rates of $\mathrm{O}_{2}$ consumption at $25^{\circ} \mathrm{C}$.

\section{Sulfide conversion}

The averaged $S_{t o t}$ profiles measured in the dark and in the light incubated mat (Fig. 1) were analyzed by a 


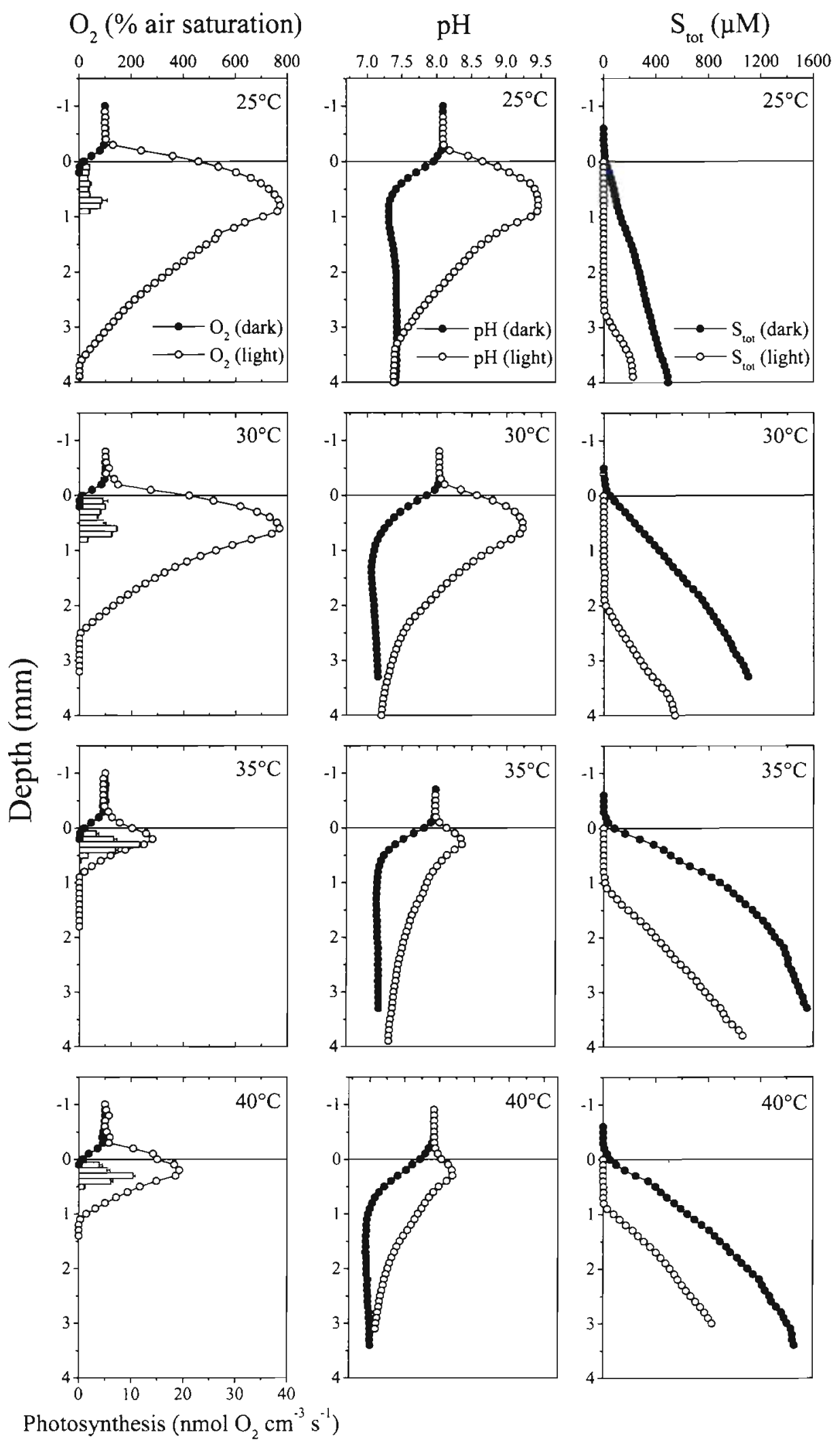

Fig. 1. Average steady-state concentration profiles ( $\mathrm{n}=2$ to 3 ) of $\mathrm{O}_{2}, \mathrm{pH}$ and $\mathrm{S}_{\mathrm{lot}}$ as a function of temperature. $\mathrm{S}_{\text {tot }}$ refers to total sulfide. Bars represent average rates of volumetric gross photosynthesis, with standard deviation indicated by error bars $(\mathrm{n}=3$ to 7$)$. ( ) measurements in the dark incubated mat, $(0)$ measurements in the light incubated mat $\left(E_{\mathrm{d}}[\mathrm{P} A \mathrm{R}]=425 \mu \mathrm{mol}\right.$ photons $\mathrm{m}^{-2} \mathrm{~s}^{-1}$ ) 
Table $1 . \mathrm{O}_{2}$ penetration, maximal $\mathrm{O}_{2}$ concentration, thickness of the photic zone, areal rates of gross photosynthesis, and maximal volumetric gross photosynthesis as a function of temperature

\begin{tabular}{|c|c|c|c|c|c|}
\hline $\begin{array}{l}\text { Temperature } \\
\quad\left({ }^{\circ} \mathrm{C}\right)\end{array}$ & $\begin{array}{c}\mathrm{O}_{2} \\
\text { penetration } \\
(\mathrm{mm})\end{array}$ & $\begin{array}{c}\text { Maximal } \mathrm{O}_{2} \\
\text { concentration } \\
(\mu \mathrm{M})\end{array}$ & $\begin{array}{l}\text { Photic } \\
\text { zone } \\
\text { (mm) }\end{array}$ & $\begin{array}{c}\text { Gross } \\
\text { photosynthesis } \\
\left.\text { (nmol } \mathrm{O}_{2} \mathrm{~cm}^{-2} \mathrm{~s}^{-1}\right)\end{array}$ & $\begin{array}{c}\text { Maximal gross } \\
\text { photosynthesis } \\
\left(\mathrm{nmol} \mathrm{O}_{2} \mathrm{~cm}^{-3} \mathrm{~s}^{-1}\right)\end{array}$ \\
\hline 25 & 3.7 & $\hat{\imath} 041 \pm 8.74$ & 0.9 & $0.22 \pm 0.01$ & $4.36 \pm 1.01$ \\
\hline 30 & 2.6 & $967 \pm 5.75$ & 0.8 & $0.36 \pm 0.01$ & $7.13 \pm 0.20$ \\
\hline 35 & 1.0 & $339 \pm 14.25$ & 0.6 & $0.30 \pm 0.01$ & $11.54 \pm 0.36$ \\
\hline 40 & 1.2 & $400 \pm 4.12$ & 0.5 & $0.27 \pm 0.01$ & $10.40 \pm 0.42$ \\
\hline
\end{tabular}

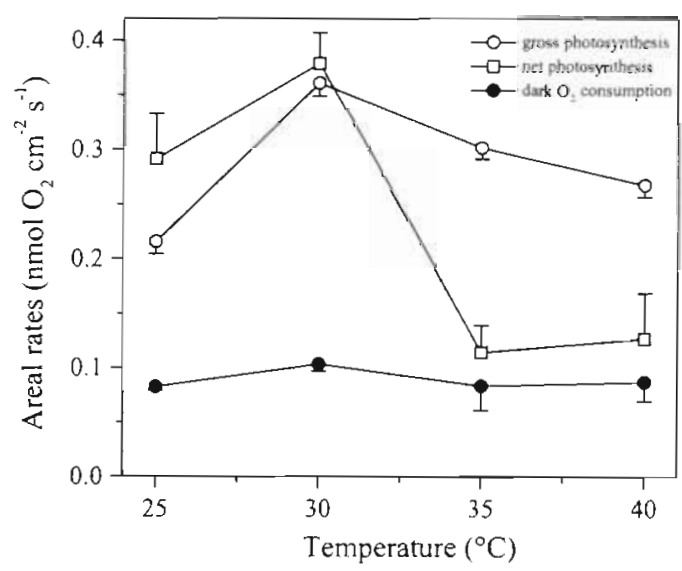

Fig. 2. Areal rates (mean $\pm S D$ ) of gross photosynthesis, net photosynthesis, and dark $\mathrm{O}_{2}$ consumption, as calculated from $\mathrm{O}_{2}$ profiles and volumetric gross photosynthetic rates shown in Fig. 1

numerical procedure (Berg et al. 1998) and zones of net sulfide production (sulfate reduction) and net sulfide consumption (aerobic chemotrophic and chemical sulfide oxidation, anoxygenic phototrophic sulfide oxidation, sulfide precipitation by $\mathrm{Fe}^{2+}$ and polysulfide formation) were identified (Fig. 3). Rates of net sulfide production (positive values) and consumption (negative values) in the dark incubated mat at $25^{\circ} \mathrm{C}$ were low as compared to the higher incubation temperatures. In the uppermost part of the mat, a zone of net sulfide production was calculated. The lack of net sulfide oxidation in that zone led to a sulfide efflux out of the mat. Below this sulfide production zone, an apparently anaerobic net sulfide consumption zone was present. An increase of the experimental temperature caused an enhancement of sulfide production. Especially at 35 and $40^{\circ} \mathrm{C}$, zones of intense sulfide production developed close to the mat surface, and the efflux of sulfide increased with temperature (Fig. 3, left panel).

In the light, the upper boundary of sulfide and, therefore, the zone of sulfide oxidation moved upwards in the mat as a result of temperature increase, following roughly the decrease in $\mathrm{O}_{2}$ penetration
(Fig. 3, right panel). With increasing temperature, a zone of sulfide production developed just below the sulfide oxidation zone. The linear part of the sulfide gradients indicate zones where no net sulfide production or consumption occurred, i.e. zones where the gradients were solely determined by sulfide diffusion. Sulfide production in the light incubated mat was most probably underestimated at 35 and $40^{\circ} \mathrm{C}$, since the curvature of the sulfide profiles in the deeper zones, where sulfide concentration gradients became less steep, were missed experimentally. The thickness of the zone where $\mathrm{O}_{2}$ and $\mathrm{S}_{\text {tot }}$ coexisted decreased with temperature, from $1.2 \mathrm{~mm}$ at $25^{\circ} \mathrm{C}$ to a minimal thickness of $0.1 \mathrm{~mm}$ at $35^{\circ} \mathrm{C}$

Areal rates of $\mathrm{O}_{2}$ consumption and net $\mathrm{S}_{\text {tot }}$ production, and the maximal possible $\mathrm{O}_{2}$ fluxes through the diffusive boundary layer towards the mat surface ( $\left.J_{\text {max }}\right)$ in the dark incubated mat are shown in Fig. 4A. The calculation of $J_{\max }$ was based on the equation for the calculation of molecular diffusion fluxes, $J$, through the diffusive boundary layer from Jorgensen \& Revsbech (1985):

$$
J=D_{0}\left(\mathrm{O}_{2}\right) \Delta\left(\mathrm{O}_{2}\right) / \mathrm{Z}_{\delta}
$$

where $D_{0}\left(\mathrm{O}_{2}\right)$ is the molecular diffusion coefficient of $\mathrm{O}_{2}, Z_{\delta}$ is the thickness of the effective diffusive boundary layer, and $\Delta\left(\mathrm{O}_{2}\right)$ is the difference between the constant bulk water $\mathrm{O}_{2}$ concentration and the $\mathrm{O}_{2}$ concentration at the mat surface. For the calculation of $J_{\text {max }}$, the $\mathrm{O}_{2}$ concentration at the mat surface was assumed to be zero and thus $\Delta\left(\mathrm{O}_{2}\right)$ equaled the concentration of dissolved $\mathrm{O}_{2}$ in the overlying Solar Lake brine $100 \%$ air saturation). $Z_{\delta}$ was determined from measured dark $\mathrm{O}_{2}$ microprofiles (Fig. 1) according to Jørgensen \& Revsbech (1985).

Measured $\mathrm{O}_{2}$ fluxes towards the dark incubated mat and calculated maximal $\mathrm{O}_{2}$ fluxes, $J_{\max }$ in the dark showed a similar temperature dependency. The differences between both rates was minimal at $30^{\circ} \mathrm{C}$ and maximal at $35^{\circ} \mathrm{C}$, with $J_{\max }$ being 12 and $22 \%$ higher than the measured actual rates of dark $\mathrm{O}_{2}$ consumption. Sulfide production in the dark increased from minimal rates of $0.024 \mathrm{nmol} \mathrm{S}$ tot $\mathrm{cm}^{-2} \mathrm{~s}^{-1}$ at $25^{\circ} \mathrm{C}$ to 


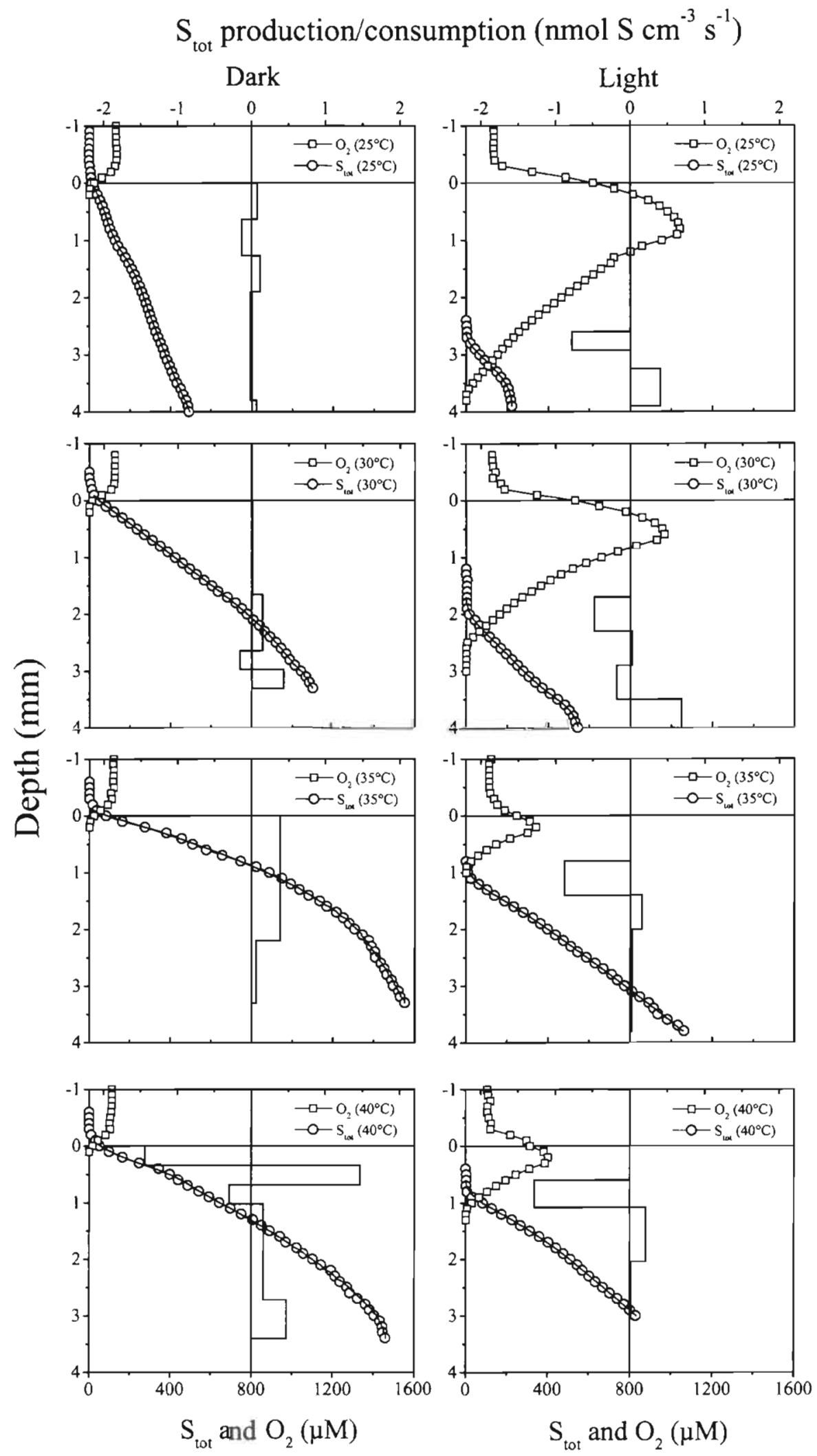

Fig. 3. Production and consumption zones of $S_{\text {tot }}$ (bars), and fitted profiles (line graph), as calculated by a numerical procedure (Berg et al. 1998) from measured steady-state $S_{\text {tot }}$ profiles (0). Zones of net $S_{\text {tot }}$ production (consumption) are plotted as positive (negative) values. (a) Oxygen profiles in the dark (left panel) and light (right panel) incubated mat 


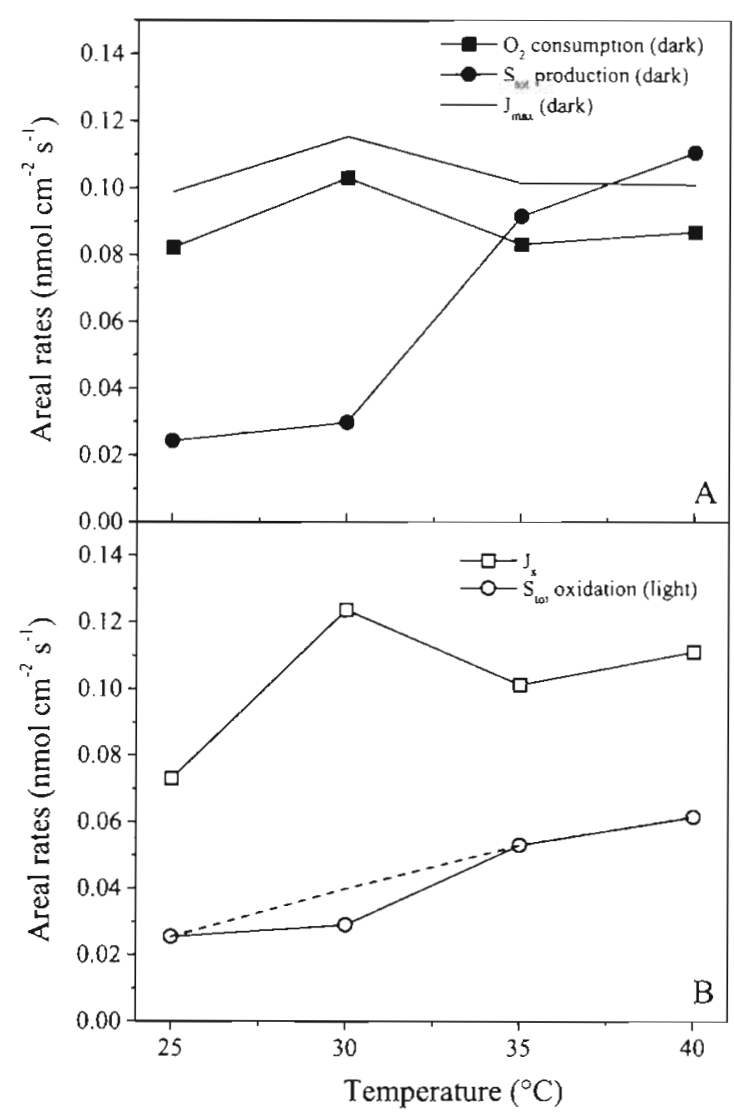

Fig. 4. (A) Areal rates of $\mathrm{O}_{2}$ consumption, net $\mathrm{S}_{10 t}$ production, and of calculated maximal possible $\mathrm{O}_{2}$ consumption ( $J_{\max }$, see text) in the dark incubated mat. (B) Areal rates of $\mathrm{O}_{2}$ consumption in the aphotic zone, $J_{s}$, net $S_{\text {tot }}$ oxidation, and net $S_{\text {tot }}$ production (----, see text) in the light incubated mat

maximal production rates of $0.111 \mathrm{nmol} \mathrm{S}_{\mathrm{tot}} \mathrm{cm}^{-2} \mathrm{~s}^{-1}$ at $40^{\circ} \mathrm{C}$. The steepest, i.e. 3 -fold, increase of areal $S_{\text {tot }}$ production rates occurred between 30 and $35^{\circ} \mathrm{C}$, where areal $\mathrm{S}_{\mathrm{tot}}$ production rates also started to exceed areal rates of dark $\mathrm{O}_{2}$ consumption.

In Fig. $4 \mathrm{~B}$ areal rates of $\mathrm{O}_{2}$ consumption in the aphotic zone, $J_{5}$ and of net sulfide oxidation at the upper sulfide boundary in the light incubated mat are shown. Taking not only net sulfide oxidation at the upper sulfide boundary into account, i.e. including also sulfide consumption zones in the deeper anoxic part of the mat, a measure of the total net sulfide production in the light incubated mat was obtained (dotted line). Areal rates of net sulfide production in the light incubated mat increased almost linearly with temperature, ranging from $0.026 \mathrm{nmol} \mathrm{S}_{\text {lot }} \mathrm{cm}^{-2} \mathrm{~s}^{-1}$ at $25^{\circ} \mathrm{C}$ to $0.061 \mathrm{nmol} \mathrm{S}_{\text {tot }} \mathrm{cm}^{-2} \mathrm{~s}^{-1}$ at $40^{\circ} \mathrm{C}$. Net sulfide oxidation at the upper sulfide boundary showed a similar trend, with a $27 \%$ lower areal rate at $30^{\circ} \mathrm{C}$, which is due to the zone of anaerobic sulfide consumption (Fig. 3). Oxygen consumption in the aphotic

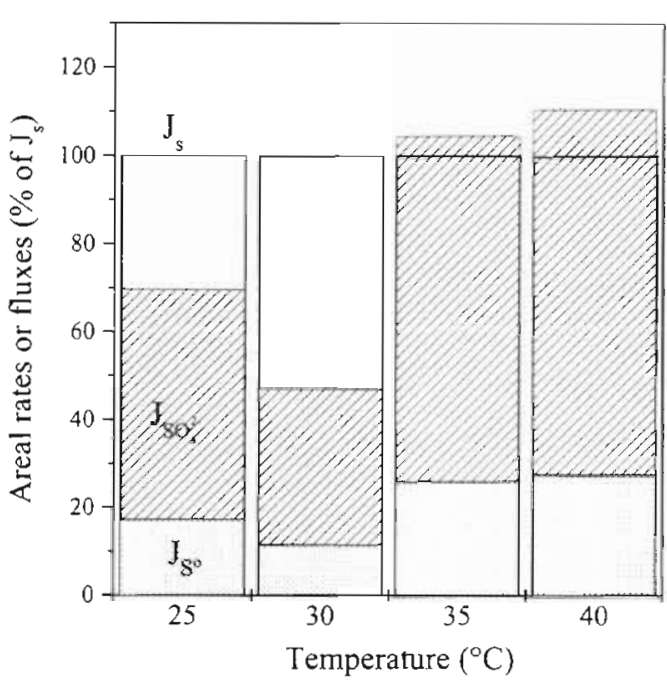

Fig. 5. Areal $\mathrm{O}_{2}$ consumption due to sulfide oxidation to elemental sulfur $\left(J_{5^{0}}\right.$, solid bars $)$ and to sulfate $\left(J_{\mathrm{SO}_{4}^{2-}}\right.$, hatched bars) relative to the overall areal $\mathrm{O}_{2}$ consumption in the aphotic zone $\left(J_{\mathrm{s}}\right)$

zone, $J_{\mathrm{s}}$ expressed as the downward $\mathrm{O}_{2}$ flux at the lower boundary of the photic zone in the light incubated mat showed a similar, but more pronounced pattern of temperature response as compared with dark $\mathrm{O}_{2}$ consumption. Maximal rates of $J_{\mathrm{s}}$ at $30^{\circ} \mathrm{C}$ amounted to $0.124 \mathrm{nmol} \mathrm{O} \mathrm{cm}^{-2} \mathrm{~s}^{-1}$.

The relative contribution of sulfide oxidation to the overall $\mathrm{O}_{2}$ consumption in the aphotic zone of the light incubated mat is shown in Fig. 5. From the sulfide oxidation rates at the upper sulfide boundary, the corresponding rates of $\mathrm{O}_{2}$ consumption, which would be needed to oxidize all sulfide either to elemental sulfur, $J_{5^{0}}$ or sulfate $J_{\mathrm{SO}_{4}^{2}}$, was calculated and expressed relative to $J_{s}$ which was determined from the measured $\mathrm{O}_{2}$ profiles. Calculations were based on the stoichiometry of the reactions (de Wit 1992):

$$
\begin{aligned}
& \mathrm{H}_{2} \mathrm{~S}+0.5 \mathrm{O}_{2} \rightarrow \mathrm{S}^{0}+\mathrm{H}_{2} \mathrm{O} \\
& \mathrm{H}_{2} \mathrm{~S}+2 \mathrm{O}_{2} \rightarrow \mathrm{SO}_{4}^{2-}+2 \mathrm{H}^{+}
\end{aligned}
$$

Aerobic sulfide oxidation to elemental sulfur would have been possible at all incubation temperatures, accounting for minimal $12 \%\left(30^{\circ} \mathrm{C}\right)$ or maximal $28 \%$ of $J_{\mathrm{s}}\left(40^{\circ} \mathrm{C}\right)$. Complete sulfide oxidation to sulfate would not have been possible at elevated temperatures (35 and $40^{\circ} \mathrm{C}$ ), even if sulfide oxidation were the only $\mathrm{O}_{2}$ consuming process in the aphotic zone. The drop of the relative contribution of sulfide oxidation to the total $\mathrm{O}_{2}$ consumption in the aphotic zone at $30^{\circ} \mathrm{C}$ is due to the much stronger temperature-induced increase of $J_{5}$ compared to the increase of sulfide oxidation (Fig. 4). Even if complete sulfide oxidation to sulfate occurred at $30^{\circ} \mathrm{C}, 53 \%$ of $J_{s}$ would still have been due to 
other $\mathrm{O}_{2}$-dependent processes (e.g. heterotrophic respiration).

\section{DISCUSSION}

Our results show that increased temperature affected both reaction rates and the depth distribution of reaction zones for processes involved in $\mathrm{O}_{2}$ and $\mathrm{S}_{\text {tot }}$ cycling in the microbial mat. Due to the numerous temperature-dependent processes and their close coupling, direct and indirect temperature effects acted in concert and determined the temperature response of the microbial community.

\section{Temperature effects on photosynthesis}

Both the thickness of the photic zone and the volumetric rates of gross photosynthesis changed with temperature (Table 1, Fig. 1). The thickness of the photic zone decreased with temperature, whereas the individual volumetric rates generally increased, with the highest maximal volumetric gross photosynthetic rate detected at $35^{\circ} \mathrm{C}$ (Table 1). Indirect temperature effects on the rates of volumetric gross photosynthesis could have been due to the temperature response of the closely associated heterotrophic community, resulting in changes of chemical gradients. The temperatureinduced decrease of the $\mathrm{pH}$ maximum in the photic zone (Fig. 1) may have been of great significance for the regulation of photosynthesis. At a given concentration of inorganic carbon, high $\mathrm{pH}$ values cause a decrease of available $\mathrm{CO}_{2}$ and vice versa. It was shown that the potential ${ }^{14} \mathrm{C}$ assimilation in homogenized surface samples from the Danish Wadden Sea (tidal sandflat) increased with decreasing $\mathrm{pH}$ (Rasmussen et al. 1983). Furthermore, increased heterotrophic activity at higher temperatures could have enhanced the $\mathrm{CO}_{2}$ supply for photosynthesis.

Temperature affected not only the volumetric gross photosynthesis rates and chemical gradients, but also the thickness of the photic zone. The most significant changes occurred between 30 and $35^{\circ} \mathrm{C}$, where a macroscopic change of the mat surface was also observed. The original brownish-orange color of the mat surface changed to a greenish-white appearance, most probably due to migration of filamentous cyanobacteria and the accumulation of elemental sulfur in the upper mat layers. The temperature-induced increase of the volumetric gross photosynthesis rates in the upper part of the mat surface could thus be explained by a direct temperature effect on photosynthesis or by an increased density of phototrophs in the surface layer caused by an upward migration of cyanobacteria.
Light-dependent migration of filamentous cyanobacteria in microbial mats is well documented in the literature (Garcia-Pichel et al. 1994, Bebout \& Garcia-Pichel 1995, Kruschel \& Castenholz 1998). Our experiments were, however, conducted at constant light conditions and thus a light-induced migration is unlikely. We cannot exclude the possibility, however, that the light field and vertical light distribution in the mat changed due to the observed changes of the mat surface. Increased light scattering in the surface layer at elevated temperatures due to the observed accumulation of elemental sulfur, in combination with high absorption due to the pronounced abundance of filamentous cyanobacteria at the mat surface, could have enhanced the light attenuation. The macroscopic change occurred at $35^{\circ} \mathrm{C}$, where sulfide production increased strongly and steep sulfide gradients prevailed in the dark incubated mat, indicating an indirect temperature-induced migration due to enhanced sulfide production. Chemotaxis, and also sulfide-induced migration in benthic cyanobacterial systems, was also suggested by Castenholz (1982) and Whale \& Walsby (1984). Thus, the observed reduction of the photic zone was most likely caused by the migration of filamentous cyanobacteria.

Areal rates of oxygenic gross photosynthesis showed an optimum curve-like response to temperature, with a significant increase between 25 and $30^{\circ} \mathrm{C}$ and a less steep decrease at increasing temperatures (Fig. 2). Maximal rates of gross photosynthesis were detected at $30^{\circ} \mathrm{C}$, which was close to the in situ sampling temperature $\left(27.5^{\circ} \mathrm{C}\right)$ and within the range of diel temperature variations in Solar Lake (Jørgensen et al. 1979). The optimum curve of gross photosynthesis in the Solar Lake mat differed from the typical response of photosynthesis to increasing temperatures, which is a progressive increase up to an optimum temperature, and a rapid decline at temperatures above the optimum temperature (Davison 1991). The most temperature-sensitive processes of photosynthesis are the enzymatic reactions involved in $\mathrm{CO}_{2}$ fixation, including the enzymes ribulose-1,5-bisphosphate carboxylase oxygenase (Rubisco) and carbonic anhydrase (Davison 1991). Furthermore, temperature effects on diffusion processes, such as diffusional supply of $\mathrm{CO}_{2} / \mathrm{HCO}_{3}^{-}$and nutrients, may also contribute to the temperature regulation of photosynthesis.

Net photosynthesis increased with temperature to an optimum at $30^{\circ} \mathrm{C}$, and then decreased strongly at $35^{\circ} \mathrm{C}$, with a slight increase again at $40^{\circ} \mathrm{C}$. A similar optimum curve-like response of net photosynthesis has also been observed in other cyanobacterial mats (Javor \& Castenholz 1984). The different temperature responses of gross and net photosynthesis are due to temperature-induced changes of $\mathrm{O}_{2}$ consumption in the light (see below). At 25 and $30^{\circ} \mathrm{C}$, net photosynthe- 
sis was higher than gross photosynthesis, and calculation of $\mathrm{O}_{2}$ consumption would result in negative rates in the light. This mismatch was also observed and discussed by E. H. G. Epping \& M. Kühl (unpubl.). They suggested that, if significant light-dependent hydrogen peroxide cycling occurs in microbial mats, this could lead to an underestimation of gross photosynthesis as determined by the light-dark shift technique. If the mismatch is caused by an underestimation of gross photosynthetic rates due to $\mathrm{H}_{2} \mathrm{O}_{2}$ metabolism, and this metabolism changes with temperature, it should also have an effect on the temperature response curve of gross photosynthesis. However, further investigations are necessary to elucidate the mismatch between gross and net photosynthesis.

\section{Temperature effects on $\mathrm{O}_{2}$ consumption in the dark}

Areal rates of dark $\mathrm{O}_{2}$ consumption showed only minor temperature-induced changes, with a maximum at $30^{\circ} \mathrm{C}$ (Fig. 2). At the given diffusional $\mathrm{O}_{2}$ supply through the diffusive boundary layer (DBL), intense $\mathrm{O}_{2}$ consumption in the mat at $25^{\circ} \mathrm{C}$ limited $\mathrm{O}_{2}$ penetration to the uppermost $0.2 \mathrm{~mm}$. Due to the DBL mass trans fer resistance, dark $\mathrm{O}_{2}$ consumption of most shallowwater sediments, microbial mats and other highly active microbial communities is limited and, therefore, regulated by the diffusional $\mathrm{O}_{2}$ flux through the DBL (Jørgensen \& Revsbech 1985, Jørgensen \& Des Marais 1990, Kühl \& Jørgensen 1992, Jørgensen 1994a). Enhanced $\mathrm{O}_{2}$ supply due to a thinner DBL and an increased $\mathrm{O}_{2}$ diffusion coefficient at increasing temperatures is partly counterbalanced by a lower $\mathrm{O}_{2}$ solubility (Jørgensen \& Revsbech 1985). Calculated rates of maximal possible dark $\mathrm{O}_{2}$ consumption, $J_{\text {max }}$ (Fig. 4A) were significantly influenced by the effective DBL thickness, $Z_{\delta}$, which was determined from the measured $\mathrm{O}_{2}$ microprofiles. $Z_{\delta}$ was minimal at $30^{\circ} \mathrm{C}$ and then increased to a maximum at $40^{\circ} \mathrm{C}$, where the mat surface topography became rougher. The difference between measured rates and calculated maximal possible rates of dark $\mathrm{O}_{2}$ consumption was minimal at $30^{\circ} \mathrm{C}$, with $J_{\text {max }}$ being $12 \%$ higher than measured rates of dark $\mathrm{O}_{2}$ consumption, thus indicating that dark $\mathrm{O}_{2}$ consumption approached the limit of $\mathrm{O}_{2}$ transport through the DBL.

Both heterotrophic aerobic respiration and oxidation of reduced inorganic compounds contributed to $\mathrm{O}_{2}$ consumption in the dark incubated mat. Since no aerobic methane oxidation activity was detected in Solar Lake microbial mats (Conrad et al. 1995), it is unlikely that this process contributed significantly to $\mathrm{O}_{2}$ consumption either in the dark or in the light incubated mat. Canfield \& Des Marais (1993) estimated that most of the $\mathrm{O}_{2}$ that diffuses into the mat (pond 5, Guerrero Negro, Baja California Sur, Mexico) at night is used for sulfide oxidation. In the Solar Lake mat, $<60 \%$ of dark $\mathrm{O}_{2}$ consumption at 25 and $30^{\circ} \mathrm{C}$ would have been due to sulfide oxidation, assuming that all (net) produced sulfide was oxidized aerobically to sulfate within the mat. Aerobic sulfide oxidation occurred very close to the mat surface, since $\mathrm{O}_{2}$ penetration at all temperatures was very low $(0.1$ to $0.2 \mathrm{~mm}$ depth, Fig. 1$)$. This narrow zone of sulfide oxidation could be the reason that no net sulfide oxidation was calculated by the numerical procedure from Berg et al. (1998). Only at $40^{\circ} \mathrm{C}$ was a net sulfide consumption zone calculated close to the mat surface (Fig. 3). This zone cannot only be attributed to aerobic sulfide oxidation since it also expands into the anoxic part of the mat, where e.g. polysulfide formation could have contributed to sulfide consumption.

With increasing temperature, the higher sulfide availability at the mat surface could have caused an $\mathrm{O}_{2}$ limitation for sulfide oxidation, which is also indicated by the observed accumulation of elemental sulfur. Even if sulfide oxidation rates increased at elevated temperatures, the formation of sulfur could have led to a slight decrease in $\mathrm{O}_{2}$ demand and thus, together with decreasing aerobic respiration, to a decrease of $\mathrm{O}_{2}$ consumption (Fig. 2). Thamdrup et al. (1998) suggested that temperature effects on benthic $\mathrm{O}_{2}$ uptake can largely be explained by the increased rates of anaerobic mineralisation and, thus, oxidation of reduced inorganic compounds at higher temperatures. Our data generally support this hypothesis, but sulfide production in the Solar Lake mat increased so strongly at elevated temperatures that sulfide oxidation became saturated and/or $\mathrm{O}_{2}$ limited.

\section{Temperature effects on $\mathrm{O}_{2}$ consumption in the light}

Oxygen consumption in the oxic zone of the light incubated mat, i.e. the difference between gross and net photosynthesis, was not calculated due to the observed mismatch between both rates (see above) However, the areal rates of gross photosynthesis and the pronounced decrease of net photosynthesis (Fig. 2) indicated that $\mathrm{O}_{2}$ consumption in the oxic zone was maximal at $35^{\circ} \mathrm{C}$. Since $\mathrm{O}_{2}$ consumption occurs both in the photic and the aphotic zone of the light incubated mat, and $\mathrm{O}_{2}$ consumption in the aphotic zone was maximal at $30^{\circ} \mathrm{C}$ (Fig. 4), $\mathrm{O}_{2}$-consuming processes in the photic zone must have contributed to the indicated maximum at $35^{\circ} \mathrm{C}$. Oxygen consumption in the photic zone can be related either to the phototrophic community or to the associated heterotrophic community. Photorespiration or consumption of produced glycolate 
could have contributed to $\mathrm{O}_{2}$ consumption in the photic zone. It was shown in hot spring cyanobacterial mats that glycolate represents a major fraction of excreted photosynthate (Bateson \& Ward 1988). Although it is generally assumed that photorespiration is low in cyanobacteria, which have a DIC (dissolved inorganic carbon)-concentrating mechanism (Aizawa \& Miyachi 1986, Colman 1989), the role of photorespiration has so far not been investigated under conditions like those observed in the Solar Lake microbial mat at the lower temperatures, where high concentrations of dissolved $\mathrm{O}_{2}$ (>7 times air saturation) occurred together with high $\mathrm{pH}(>9)$. High temperatures increase the potential for photorespiration (Davison 1991), but $\mathrm{O}_{2}$ concentrations and $\mathrm{pH}$, and thus probably also the $\mathrm{O}_{2} / \mathrm{CO}_{2}$ ratios, were much lower at 35 and $40^{\circ} \mathrm{C}$ as compared to 25 and $30^{\circ} \mathrm{C}$, indicating less favorable conditions for photorespiration. Oxygen consumption in the photic zone at $35^{\circ} \mathrm{C}$ could also have been influenced by the observed changes of the surface layer.

In several systems, the excretion of organic compounds by primary producers and the subsequent uptake or turnover of these compounds by heterotrophic bacteria has been indicated (e.g. Haack \& McFeters 1982, Bateson \& Ward 1988, Neely \& Wetzel 1995, Malinsky-Rushansky \& Legrand 1996). A close coupling of heterotrophic processes and photosynthesis has been suggested for cyanobacterial mats (Canfield \& Des Marais 1993, Teske et al. 1998) and epilithic cyanobacterial biofilms (Kühl et al. 1996). Zlotnik \& Dubinsky (1989) suggested that significant excretion of dissolved organic carbon from phytoplankton occurs under conditions favorable for photosynthesis, i.e. when photosynthetic rates are high.

Both areal rates of gross photosynthesis (Fig. 2) and areal $\mathrm{O}_{2}$ consumption in the aphotic zone, $J_{5}$ (Fig. 4), were maximal at $30^{\circ} \mathrm{C}$ and minimal at $25^{\circ} \mathrm{C}$. Moreover, it is indicated that aerobic heterotrophic processes contributed significantly to $J_{5}$ at $30^{\circ} \mathrm{C}$ (Fig. 5), possibly driven by a pronounced excretion of photosynthate at maximal rates of gross photosynthesis. However, $J_{\mathrm{s}}$ includes all biological and chemical $\mathrm{O}_{2}$-consuming processes (e.g. aerobic respiration and oxidation of reduced inorganic compounds) in the aphotic zone.

At higher temperatures, sulfide production increased and $\mathrm{O}_{2}$ penetration decreased significantly, pointing to an increasing contribution of sulfide oxidation to the overall $\mathrm{O}_{2}$ consumption in the aphotic zone. Although sulfide can be oxidized both biologically and chemically, chemical sulfide oxidation is generally slower than biological oxidation of sulfide (e.g. Buisman et al. 1990). Revsbech et al. (1983) found that sulfjde oxidation in the illuminated Solar Lake mat was primarily biologically mediated. An exact contribution of sulfide oxidation to $\mathrm{O}_{2}$ consumption in the aphotic zone cannot, however, be determined, since the $\mathrm{O}_{2}$ demand for sulfide oxidation depends strongly on the oxidation product, on the microorganisms involved in sulfide oxidation, and also on the biological and chemical conversions of intermediate sulfide oxidation products. Furthermore, our microsensor measurements were not done at exactly the same point and a direct correlation of overlapping reaction zones of $\mathrm{O}_{2}$ consumption and sulfide oxidation is critical. However, the measured $\mathrm{O}_{2}$ and $\mathrm{S}_{\text {tot }}$ profiles showed clearly that (1) sulfide oxidation, referred to as the $S_{10 t}$ consumption at the upper boundary of the profile, increased with temperature (Fig. 4); and (2) there was a pronounced change in $\mathrm{O}_{2}$ availability for sulfide oxidation with temperature (Fig. 3). The $\mathrm{O}_{2}$ availability can affect the types of sulfide oxidation products formed, as has been shown e.g. for Thiobacillus thioparus (van den Ende \& van Gemerden 1993).

Different oxidation states of intermediate sulfide oxidation products do significantly influence the contribution of sulfide oxidation to $\mathrm{O}_{2}$ consumption in the aphotic zone. Only at 25 and $30^{\circ} \mathrm{C}$ would complete sulfide oxidation have been possible, as estimated from $J_{5}$ and calculated rates of sulfide oxidation (Fig. 5). At these temperatures, the zone of sulfide oxidation overlapped significantly with the aphotic zone (Fig. 3). It is thus likely that complete sulfide oxidation, or at least oxidation to highly oxidized intermediates, occurred at 25 and $30^{\circ} \mathrm{C}$. The situation changed drastically with increasing temperature. At higher temperatures complete sulfide oxidation would not have been possible, even if only sulfide oxidation contributed to $J_{\mathrm{s}}$ (Fig. 5). At $35^{\circ} \mathrm{C}$, the thickness of the zone where $\mathrm{O}_{2}$ and $\mathrm{S}_{\text {tot }}$ coexisted was minimal ( $0.1 \mathrm{~mm}$, Fig. 3). Therefore, the possibility of anoxic sulfide consumption by, e.g., anoxygenic photosynthesis (see below) and polysulfide formation cannot be excluded at $35^{\circ} \mathrm{C}$, and this could have led to a lower $\mathrm{O}_{2}$ demand for sulfide oxidation. At $40^{\circ} \mathrm{C}, J_{\mathrm{s}}$ increased again (Fig. 4), as a result of increasing sulfide oxidation and a slightly higher $\mathrm{O}_{2}$ availability. Although the zone of sulfide oxidation was restricted to the aphotic zone, complete sulfide oxidation to sulfate was not possible, even if only sulfide oxidation would have contributed to $\mathrm{O}_{2}$ consumption in the aphotic zone. Taking also $\mathrm{O}_{2}$ consumption by aerobic respiration into account, it is probable that intermediate sulfide oxidation products with a low oxidation state accumulated due to incomplete sulfide oxidation.

Anoxygenic photosynthesis was not of major importance for sulfide oxidation, since $\mathrm{O}_{2}$ penetrated deeper than the depth of the photic zone and, except at $35^{\circ} \mathrm{C}$, $\mathrm{O}_{2}$ and $\mathrm{S}_{\text {tot }}$ consumption zones overlapped. This points to a predominance of chemolithotrophic sulfide oxidation (Jørgensen \& Des Marais 1986). However, incomplete aerobic sulfide oxidation under $\mathrm{O}_{2}$ limitation 
could also support anoxygenic phototrophs via intermediate sulfide oxidation products (van den Ende et al. 1996), thus allowing for a coexistence of both processes. The latter is also indicated by the increased abundance of Chloroflexus-type filamentous bacteria in the surface layer, as observed by light microscopy after the experiments. Although we did not measure the vertical light distribution in the mat, enough light, especially near-infrared light (Jørgensen et al. 1979), could have penetrated to the zone of sulfide oxidation at elevated temperatures. The use of intermediates is however not detectable with $\mathrm{H}_{2} \mathrm{~S}$ microelectrodes. Sulfide oxidation is also simplified if only sulfate and elemental sulfur as oxidation products are considered. Other possible intermediates like thiosulfate could also have been produced and further transformed via oxidation, reduction or disproportionation (e.g. Jørgensen 1990, 1994b, Visscher et al. 1992). Disproportionation reactions of different intermediates (e.g. thiosulfate, sulfite) can lead to additional sulfide production (Bak \& Cypionka 1987, Bak \& Pfennig 1987). Thus, our sulfide consumption rates may represent part of the actual rates of chemolithotrophic and anoxygenic phototrophic processes in the mat.

\section{Temperature eifects on $\mathrm{pH}$ microprofiles}

The measured pH profiles are difficult to interpret in terms of specific chemical or biological processes. In the dark, $\mathrm{pH}$ decreased in the upper part of the mat. Since sulfide oxidation and heterotrophic respiration took place in the upper $0.2 \mathrm{~mm}$ of the dark incubated mat, the overall $\mathrm{pH}$ decrease with depth was probably also due to fermentation processes by fermentative heterotrophic bacteria and/or cyanobacteria (Oren \& Shilo 1979, Moezelaar et al. 1996, Nold \& Ward 1996). Fermentation increased with temperature as indicated from the decreasing $\mathrm{pH}$ in the upper part of the dark incubated mat. Accumulation of fermentation products under dark anaerobic conditions was shown in hot spring cyanobacterial mats (Anderson et al. 1987). Such fermentation products could serve as substrates for sulfate-reducing bacteria (Moezelaar et al. 1996). Furthermore, fermentative production of $\mathrm{H}_{2}$ could support sulfate reduction in the dark (Skyring et al. 1988).

The $\mathrm{pH}$ maximum in the photic zone represents the balance between the photosynthetically induced $\mathrm{pH}$ increase due to $\mathrm{CO}_{2}$ fixation and heterotrophic activity, which tends to decrease the $\mathrm{pH}$. The $\mathrm{pH}$ decrease in the aphotic zone was caused by aerobic respiration and sulfide oxidation. The chemical gradients and thus the depth distribution of these processes changed significantly with temperature (Fig. 3), contributing to the observed temperature-enhanced $\mathrm{pH}$ decrease in the aphotic zone and to the decrease of the photosynthesis-induced $\mathrm{pH}$ maximum.

\section{Temperature effects on sulfide production}

Sulfide production increased with temperature, both in the dark and light incubated mat (Figs. $3 \& 4$ ). The $Q_{10}$ of sulfide production was determined according to Isaksen \& Jørgensen (1996). In the temperature range of 25 to $35^{\circ} \mathrm{C}\left(30\right.$ to $\left.40^{\circ} \mathrm{C}\right)$ a $Q_{10}$ of $1.82(1.78)$ in the light and a $Q_{10}$ of $3.16(3.05)$ in the dark incubated mat was calculated. Generally, reported $Q_{10}$ values of sulfate reduction in cyanobacterial mats and saltmarsh sediments are in the range of 2.0 to 3.5 (Abdollahi \& Nedwell 1979, Skyring et al. 1983, Jørgensen 1994 b). In other hypersaline mats, a $10^{\circ} \mathrm{C}$ temperature increase caused a 2 to 4 -fold enhancement of sulfate reduction both during the day and night (Canfield \& Des Marais 1991, 1993).

Our sulfide production rates represent net rates of sulfide production, which, together with sulfide consumption rates, represent a measure of net sulfide cycling in the mat. Actual rates of sulfate reduction may have been higher at all conditions. High rates of sulfate reduction have been measured in the uppermost few $\mathrm{cm}$ in Solar Lake mats, and it was found that $50 \%$ of the total daily areal sulfate reduction occurred in the uppermost $5 \mathrm{~mm}$ and $90 \%$ in the uppermost $3 \mathrm{~cm}$ of the mat, respectively (Jørgensen \& Cohen 1977). Furthermore, several studies indicate that sulfate reduction also occurs in the well-oxygenated zone of light incubated hypersaline mats, where the produced sulfide is rapidly reoxidized (Canfield \& Des Marais 1991, Fründ \& Cohen 1992, Jørgensen 1994b, Teske et al. 1998). These processes are not included in our net sulfide production rates, which could be one reason for the different $Q_{10}$ values of sulfide production in the dark and light incubated mat.

The most pronounced increase of sulfide production in the dark incubated mat occurred between 30 and $35^{\circ} \mathrm{C}$ (Fig. 4), and a zone of high sulfide production developed in the upper layer of the mat (Fig. 3). This significant increase could have been due to both a higher temperature optimum of the sulfate-reducing bacterial community and possibly an increased availability of electron donors. Thus, sulfate reduction became of increasing importance for the mineralisation of organic matter at elevated temperatures. A stronger temperature dependency of sulfate reduction than aerobic respiration and an increased role of anaerobic mineralisation at increasing temperatures was also suggested by Thamdrup et al. (1998) in a study of suspended marine sediments.

The measured $S_{\text {tot }}$ profiles did not always exhibit a clear spatial separation of sulfide production and con- 
sumption zones, and sometimes several zones were calculated by the numerical procedure (Fig. 3). Especially at $40^{\circ} \mathrm{C}$ in the dark incubated mat, zones of high sulfide production and consumption were calculated close to the mat surface and it is difficult to estimate if these zones are only due to biological sulfide production/consumption processes or if various chemical processes like polysulfide formation via reactions between sulfide and elemental sulfur took place. Also the occurrence of zones of anaerobic sulfide consumption under several conditions (Fig. 3) is difficult to interpret. Besides chemical reactions, these zones could also result from changes of physical parameters in the mat, like the porosity and the diffusion coefficient $D_{s}$ which were assumed to be constant.

\section{CONCLUSIONS}

Temperature had a complex effect on processes involved in $\mathrm{O}_{2}$ and sulfide cycling in the Solar Lake cyanobacterial mat. Most of the involved microbial processes are not only directly regulated by temperature, but also depend on the availability of various substrates, either supplied by closely associated microbial activities or by diffusional transport. These are also temperature dependent and therefore contributed indirectly to the temperature response of, e.g., photosynthesis and $\mathrm{O}_{2}$ consumption. In the Solar Lake mat, sulfide conversion processes became of increasing importance for the $\mathrm{O}_{2}$ turnover at elevated temperatures. Thus, when temperature was increased above in situ environmental temperatures, the sulfur cycle strongly influenced the aerobic community and its metabolism, and became a major controlling factor of carbon turnover in the microbial mat.

Acknowledgements. This study was supported by the Red Sea Program on Marine Sciences, Project E: Microbial activities in marine interfaces controlling sediment-water fluxes, financed by the German Ministry of Education and Research (BMBF). M.K. acknowledges the support by the Danish Natural Science Research Council. We thank Gaby Eickert, Anja Eggers and Vera Hubner for the construction of the microsensors, and Gaby Eickert for technical assistance in Eilat. We acknowledge the fruitful discussions with Carsten Steuckart, Ferran Garcia-Pichel and Peter Berg. The Interuniversity Institute in Eilat (Israel) is thanked for providing laboratory facilities, and especially Yehuda Cohen is thanked for his hospitality and for never-ending enthusiasm and efforts to arrange the Solar Lake field trips. The Egyptian authorities are thanked for their permission to work at Solar Lake.

\section{LITERATURE CITED}

Abdollahi H, Nedwell DB (1979) Seasonal temperature as a factor influencing bacterial sulfate reduction in a saltmarsh sediment. Microb Ecol 5:73-79
Aizawa K, Miyachi S (1986) Carbonic anhydrase and CO concentrating mechanisms in microalgae and cyanobacteria. FEMS Microbiol Rev 39:215-233

Aizenshtat Z, Lipiner G, Cohen Y (1984) Biogeochemistry of carbon and sulfur cycle in the microbial mats of the Solar Lake (Sinai). In: Cohen Y, Castenholz RW, Halvorson HO (eds) Microbial mats: stromatolites. Alan R Liss, New York, p 281-312

Anderson KL, Tayne TA, Ward DM (1987) Formation and fate of fermentation products in hot spring cyanobacterial mats. Appl Environ Microbiol 53(10):2343-2352

Bak F, Cypionka H (1987) A novel type of energy metabolism involving fermentation of inorganic sulphur compounds. Nature 326:891-892

Bak F, Pfennig N (1987) Chemolithotrophic growth of Desulfovibrio sulfodismutans $\mathrm{sp}$. nov. by disproportionation of inorganic sulfur compounds. Arch Microbiol 147:184-189

Bateson MM, Ward DM (1988) Photoexcretion and fate of glycolate in a hot spring cyanobacterial mat. Appl Environ Microbiol 54(7):1738-1743

Bebout BM, Garcia-Pichel F (1995) UV B-induced vertical migrations of cyanobacteria in a microbial mat. Appl Environ Microbiol 61(12):4215-4222

Berg P, Risgaard-Petersen N, Rysgaard S (1998) Interpretation of measured concentration profiles in sediment pore water. Limnol Oceanogr 43(7):1500-1510

Broecker WS, Peng TH (1974) Gas exchange rates between air and sea. Tellus 26:21-35

Buisman C, Ijspeert P, Janssen A, Lettinga G (1990) Kinetics of chemical and biological sulphide oxidation in aqueous solutions. Water Res 24(5):667-671

Canfield DE, Des Marais DJ (1991) Aerobic sulfate reduction in microbial mats. Science 251:1471-1473

Canfield DE, Des Marais DJ (1993) Biogeochemical cycles of carbon, sulfur, and free oxygen in a microbial mat. Geochim Cosmochim Acta 57:3971-3984

Castenholz RW (1982) Motility and taxes. In: Carr NG, Whitton BA (eds) The biology of cyanobacteria. Blackwell Scientific Publications, Oxford, p 413-440

Cline JD (1969) Spectrophotometric determination of hydrogen sulfide in natural waters. Limnol Oceanogr 14: $454-458$

Cohen Y, Krumbein WE, Goldberg M, Shilo M (1977) Solar Lake (Sinai). 1. Physical and chemical limnology. Limnol Oceanogr 22(4):597-608

Cohen Y, Jørgensen BB, Revsbech NP, Poplawski R (1986) Adaptation to hydrogen sulfide of oxygenic and anoxygenic photosynthesis among cyanobacteria. Appl Environ Microbiol 51(2):398-407

Colman B (1989) Photosynthetic carbon assimilation and the suppression of photorespiration in the cyanobacteria. Aquat Bot 34:211-231

Conrad R, Frenzel P, Cohen Y (1995) Methane emission from hypersaline microbial mats: lack of aerobic methane oxidation activity. FEMS Microbiol Ecol 16:297-306

Davison IR (1991) Environmental effects on algal photosynthesis: temperature. J Phycol 27:2-8

de Wit R (1992) Sulfide-containing environments. Encyclopedia Microbiol 4:105-121

de Wit R, van Gemerden H (1987) Chemolithotrophic growth of the phototrophic sulfur bacterium Thiocapsa roseopersicina. FEMS Microbiol Ecol 45:117-126

Fründ C, Cohen Y (1992) Diurnal cycles of sulfate reduction under oxic conditions in cyanobacterial matss. Appl Environ Microbiol 58(1):70-77

Garcia-Pichel F, Mechling M, Castenholz RW (1994) Diel migrations of microorganisms within a benthic, hyper- 
saline mat community. Appl Environ Micrabiol 60(5): $1500-1511$

Garcia-Pichel F, Nübel U, Muyzer G (1998) The phylogeny of unicellular, extremely halotolerant cyanobacteria. Arch Microbiol 169:469-482

Grant J (1986) Sensitivity of benthic community respiration and primary production to changes in temperature and light. Mar Biol 90:299-306

Grasshoff K (1983) Determination of $\mathrm{pH}$. In: Grasshoff $\mathrm{K}$, Ehrhardt $M$, Kremling $K$ (eds) Methods of seawater analysis. Verlag Chemie, Weinheim, p 85-97

Haack TK, McFeters GA (1982) Nutritional relationship among microorganisms in an epilithic biofilm community. Microb Ecol 8:115-126

Hershey JP, Plese T, Millero FJ (1988) The $p K_{1}{ }^{*}$ for the dissociation of $\mathrm{H}_{2} \mathrm{~S}$ in various ionic media. Geochim Cosmochim Acta 52:2047-2051

Isaksen MF, Jørgensen BB (1996) Adaptation of psychrophilic and psychrotrophic sulfate-reducing bacteria to permanently cold marine environments. Appl Environ Microbiol 62(2):408-414

Javor BJ, Castenholz RW (1984) Productivity studies of microbial mats, Laguna Guerrero Negro, Mexico. In: Cohen Y, Castenholz RW, Halvorson $\mathrm{HO}$ (eds) Microbial mats: stromatolites. Alan R Liss, New York, p 149-170

Jensen J, Revsbech NP (1989) Photosynthesis and respiration of a diatom biofjlm cultured in a new gradient growth chamber. FEMS Microbiol Ecol 62:29-38

Jeroschewski P, Steuckart C, Kühl M (1996) An amperometric microsensor for the determination of $\mathrm{H}_{2} \mathrm{~S}$ in aquatic environments. Anal Chem 68:4351-4357

Jørgensen BB (1990) A thiosulfate shunt in the sulfur cycle of marine sediments. Science 249:152-154

Jørgensen BB (1994a) Diffusion processes and boundary layers in microbial mats. In: Stal LJ, Caumette P (eds) Microbial mats: structure, development and environmental significance. NATO ASI Series G, Vol 35. Springer, Berlin, p 243-253

Jørgensen BB (1994b) Sulfate reduction and thiosulfate transformations in a cyanobacterial mat during a diel oxygen cycle. FEMS Microbiol Ecol 13(4):303-312

Jargensen BB, Cohen Y (1977) Solar Lake (Sinai). 5. The sulfur cycle of the benthic cyanobacterial mats. Limnol Oceanogr 22(4):657-666

Jørgensen BB, Des Marais DJ (1986) Competition for sulfide among colorless and purple sulfur bacteria in cyanobacterial mats. FEMS Microbiol Ecol 38:179-186

Jørgensen BB, Des Marais DJ (1990) The diffusive boundary layer of sediments: oxygen microgradients over a microbial mat. Limnol Oceanogr 35(6):1343-1355

Jørgensen BB, Revsbech NP (1985) Diffusive boundary layers and the oxygen uptake of sediments and detritus. Limnol Oceanogr 30(1):111-122

Jørgensen BB, Revsbech NP, Blackburn TH, Cohen Y (1979) Diurnal cycle of oxygen and sulfide microgradients and microbial photosynthesis in a cyanobacterial mat sediment. Appl Environ Microbiol 38(1):46-58

Jørgensen BB, Revsbech NP, Cohen Y (1983) Photosynthesis and structure of benthic microbial mats: microelectrode and SEM studies of 4 cyanobacterial communities. Limnol Oceanogr 28(6):1075-1093

Jørgensen BB, Cohen Y, Revsbech NP (1986) Transition from anoxygenic to oxygenic photosynthesis in a Microcoleus chthonoplastes cyanobacterial mat. Appl Environ Microbiol 51(2):408-417

Krekeler D, Sigalevich P, Teske A, Cypionka H, Cohen Y (1997) A sulfate-reducing bacterium from the oxic layer of a microbial mat from Solar Lake (Sinai), Desulfovibrio oxyclinae sp. nov. Arch Microbiol 167:369-375

Krekeler D, Teske A, Cypionka H (1998) Strategies of sulfatereducing bacteria to escape oxygen stress in a cyanobacterial mat. FEMS Microbiol Ecol 25:89-96

Krumbein WE, Cohen Y, Shilo M (1977) Solar Lake (Sinai). 4. Stromatolitic cyanobacterial mats. Limnol Oceanogr $22(4): 635-656$

Kruschel C, Castenholz RW (1998) The effect of solar UV and visible irradiance on the vertical movements of cyanobacteria in microbial mats of hypersaline waters. FEMS Microbiol Ecol 27:53-72

Kühl M, Jørgensen BB (1992) Microsensor measurements of sulfate reduction and sulfide oxidation in compact microbial communities of aerobic biofilms. Appl Environ Microbiol 58(4):1164-1174

Kühl M., Glud RN, Ploug H, Ramsing NB (1996) Nlicroenvironmental control of photosynthesis and photosyrthesiscoupled respiration in an epilithic cyanobacterial biofilm. J Phycol 32:799-812

Kühl M, Steuckart C, Eickert G, Jeroschewski P (1998) A H $\mathrm{H}_{2} \mathrm{~S}$ microsensor for profiling biofilms and sediments: application in an acidic lake sediment. Aquat Microb Ecol 15 201-209

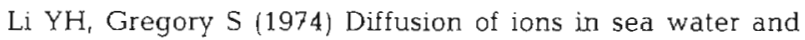
in deep-sea sediments. Geochim Cosmochim Acta 38 $703-714$

Lorenzen J, Glud RN, Revsbech NP (1995) Impact of microsensor-caused changes in diffusive boundary layer thickness on $\mathrm{O}_{2}$ profiles and photosynthetic rates in benthic communities of microorganisms. Mar Ecol Prog Ser 119:237-241

Malinsky-Rushansky NZ, Legrand C (1996) Excretion of dissolved organic carbon by phytoplankton of different sizes and subsequent bacterial uptake. Mar Ecol Prog Ser 132 $249-255$

Moezelaar R, Bijvank SM, Stal LJ (1996) Fermentation and sulfur reduction in the mat-building cyanobacterium Microcoleus chthonoplastes. Appl Environ Microbiol 62(5): $1752-1758$

Neely RK, Wetzel RG (1995) Simultaneous use of ${ }^{14} \mathrm{C}$ and ${ }^{3} \mathrm{H}$ to determine autotrophic production and bacterial protein production in periphyton. Microb Ecol 30:227-237

Nold SC, Ward DM (1996) Photosynthate partitioning and fermentation in hot spring microbial mat communities. Appl Environ Microbiol 62(12):4598-4607

Oren A, Shilo $M$ (1979) Anaerobic heterotrophic dark metabolism in the cyanobacterium Oscillatoria limnetica: sulfur respiration and lactate fermentation. Arch Microbiol 122 $77-84$

Por FD (1969) Limnology of the heliothermal Solar Lake on the coast of Sinai (Gulf of Elat). Int Ver Theor Angew Limnol Verh 17:1031-1034.

Rasmussen MB, Henriksen K, Jensen A (1983) Possible causes of temporal fluctuations in primary production of the microphytobenthos in the Danish Wadden Sea. Mar Biol 73:109-1.14

Revsbech NP (1989) An oxygen microelectrode with a guard cathode. Limnol Oceanogr 34:474-478

Revsbech NP, Jørgensen BB (1983) Photosynthesis of benthic microflora measured with high spatial. resolution by the oxygen microprofile method: capabilities and limitations of the method. Limnol Oceanogr 28(4):749-756

Revsbech NP, Jørgensen BB (1986) Microelectrodes: their use in microbial ecology. Adv Microb Ecol 9:293-352

Revsbech NP, Jørgensen BB, Brix O (1981) Primary production of microalgae in sediments measured by oxygen 
microprofile, $\mathrm{H}^{14} \mathrm{CO}_{3}^{-}$fixation, and oxygen exchange methods. Limnol Oceanogr 26(4):717-730

Revsbech NP, Jørgensen BB, Blackburn TH, Cohen Y (1983) Microelectrode studies of the photosynthesis and $\mathrm{O}_{2}, \mathrm{H}_{2} \mathrm{~S}$, and $\mathrm{pH}$ profiles of a microbial mat. Limnol Oceanogr 28(6):1062-1074

Schidlowski M, Matzigkeit U, Krumbein WE (1984) Superheavy organic carbon from hypersaline microbial mats. Naturwissenschaften 71:303-308

Schopf JW, Klein C (1992) The proterozoic biosphere: a multidisciplinary study. Cambridge University Press, Cambridge

Sherwood JE, Stagnitti F, Kokkinn MJ, Williams WD (1991) Dissolved oxygen concentrations in hypersaline waters. Limnol Oceanogr 36(2):235-250

Skyring GW (1987) Sulfate reduction in coastal ecosystems. Geomicrobiol J 5:295-374

Skyring GW, Chambers LA, Bauld J (1983) Sulfate reduction in sediments colonized by cyanobacteria, Spencer Gulf, South Australia. Aust J Mar Freshw Res 34:359-374

Skyring GW, Lynch RM, Smith GD (1988) Acetylene reduction and hydrogen metabolism by a cyanobacterial/sulfate-reducing bacterial mat ecosystem. Geomicrobiol J 6:25-31

Teske A, Ramsing NB, Habicht K, Fukui M, Küver J, Jørgensen BB, Cohen Y (1998) Sulfate-reducing bacteria and their activities in cyanobacterial mats of Solar Lake (Sinai, Egypt). Appl Environ Microbiol 64(8):2943-2951

Editorial responsibility: Otto Kinne (Editor),

Oldendorf/Luhe, Germany
Thamdrup B, Hansen JW, Jørgensen BB (1998) Temperature dependence of aerobic respiration in a coastal sediment. FEMS Microbiol Ecol 25:189-200

Ulman WJ, Aller RC (1982) Diffusion coefficients in nearshore marine sediments. Limnol Oceanogr 27(3):552-556

van den Ende FP, van Gemerden H (1993) Sulfide oxidation under oxygen limitation by a Thiobacillus thioparus isolated from a marine microbial mat. FEMS Microbiol Ecol 13:69-78

van den Ende FP, Laverman AM, van Gemerden H (1996) Coexistence of aerobic chemotrophic and anaerobic phototrophic sulfur bacteria under oxygen limitation. FEMS Microbiol Ecol 19:141-151

van Gemerden H (1993) Microbial mats: a joint venture. Mar Geol 113:3-25

Visscher PT, Prins RA, van Gemerden H (1992) Rates of sulfate reduction and thiosulfate consumption in a marine microbial mat. FEMS Microbiol Ecol 86:283-294

Westrich JT, Berner RA (1988) The effect of temperature on rates of sulfate reduction in marine sediments. Geomicrobiol J 6:99-117

Whale GF, Walsby AE (1984) Motility of the cyanobacterium Microcoleus chthonoplastes in mud. $\mathrm{Br}$ Phycol J 19: $117-123$

Zlotnik I, Dubinsky Z (1989) The effect of light and temperature on DOC excretion by phytoplankton. Limnol Oceanogr 34(5):831-839

Submitted: March 17, 1999; Accepted: November 4, 1999 Proofs received from author(s): March 24, 2000 